\title{
Evaluation of In Vitro Antioxidant and Antimicrobial Activities of Green Microalgae Trentepohlia umbrina
}

\author{
Snežana SIMIĆ, Marijana KOSANIĆ*, Branislav RANKOVIĆ \\ University of Kragujevac, Faculty of Science, Department of Biology, Radoja Domanovića 12, 34000 \\ Kragujevac, Serbia; marijanakosanic@yahoo.com ('correspondingauthor)
}

\begin{abstract}
The aim of the study is to examine in vitro antioxidant and antimicrobial activities of the methanol extract of the green microalga Trentepohlia umbrina. Antioxidant activity was evaluated by five different methods: free radical scavenging, superoxide anion radical scavenging, reducing power, determination of total phenolic compounds and determination of total flavonoid content. As a result of the study methanol extract of Trentepohlia umbrina had moderate free radical scavenging activity with $\mathrm{IC}_{50}$ values $665.28 \mu \mathrm{g} / \mathrm{ml}$. Moreover, the tested extract had effective reducing power and superoxide anion radical scavenging. Total content of phenol and flavonoid in extract were determined as pyrocatechol equivalent, and as rutin equivalent, respectively. The antimicrobial activity was estimated by determination of the minimal inhibitory concentration by the broth microdilution method against five species of bacteria and five species of fungi, including agents of human, animal and plant diseases, mycotoxin producers, and food spoilage agents. Generally, the tested extract had relatively strong antimicrobial activity against the tested microorganisms with minimum inhibitory concentration values ranging from 1.25 to $5 \mathrm{mg} / \mathrm{ml}$. The present study shows that tested methanol extract demonstrated relatively strong antioxidant and antimicrobial activities. It suggests that this microalga may be used as good sources of natural antioxidant and antimicrobial agents.
\end{abstract}

Keywords: algae, biological activity, methanol extract

\section{Introduction}

Oxidative stress is initiated by reactive oxygen species (ROS), such as superoxide anion radicals $\left(\mathrm{O}_{2}^{-}\right)$, hydrogen peroxide $\left(\mathrm{H}_{2} \mathrm{O}_{2}\right)$, hydroxyl radicals $(\mathrm{OH})$ and singlet oxygen $\left({ }^{1} \mathrm{O}_{2}\right)$. At normal physiological concentrations ROS are required for cellular activities. However, at higher concentrations, ROS can be toxic, leading to the development of over hundred of diseases which range from arthritis and connective tissue disorders to carcinogenesis, physical injury, infection and acquired immunodeficiency syndrome (Athar Abbasi et al., 2012).

The most effective way of eliminating ROS which cause the oxidative stress is with the help of antioxidants. Antioxidants, both synthetic or natural, can be effective to help human body in reducing oxidative damage by ROS (Souri et al., 2008). However, recently, it is suspected that synthetic antioxidants such as butylated hydroxyanisole (BHA), butylated hydroxytoluene (BHT), tert-butylhydroquinone (TBHQ) and propyl gallate (PG) have demonstrated toxic and carcinogenic effects (Kosanić et al., 2011). For this reason, significant attention has been given to natural antioxidants for their capacity to protect organisms from damage induced by oxidative stress (Gulcin et al., 2004). In order to find new natural sources of antioxidants, attention was focused on algae.

Algal organisms are rich sources of structurally novel and biologically active metabolites. Secondary or primary metabolites produced by these organisms may be potential bioactive compounds of interests in the pharmaceutical industry (Ely et al., 2004; Tuney et al., 2006). Algae produce a number of secondary metabolites as a chemical defense against predation, herbivores and competition for space (De lara Isassi et al., 2000). Since algae have been used in traditional medicine for a long time and also some algae have bacteriostatic, bactericidal, antifungal, antiviral and antitumor activity, they have been extensively studied by several researchers (Justo et al., 2001; Saeidnia et al., 2009; Uma et al., 2011a).

Trentepoblia spp. of the aerial Chlorophyceae are cosmopolitan, occurring mainly in the tropical and subtropical regions. The algae are considered to have a high tolerance and adaptability to severe conditions such as desiccation and high temperatures. The colonies of Trentepoblia spp. are a reddish orange to green under various conditions. Trentepoblia spp. are known to possess a large amount of carotenoids, especially $\beta$-carotene, when the algal cells turn reddish orange. $\beta$-carotene is an essential component of the light-harvesting complexes and reaction centers of the photosynthetic apparatus. Carotenoids protect chlorophylls, and the thylakoid membrane is protected against photooxidative damage by absorbing an excess amount of solar energy (Abe et al., 1998).

Trentepohlia umbrina is one of the most widespread species of the genus; records exist for almost all regions of the world where Trentepobliales have been collected. 
Sarma (1986) reported the data on its distribution in $\mathrm{Eu}-$ rope. This species is found in many countries such as Austria, Britain, Bulgaria, Germany, Greece, Latvia, Norway, Portugal, Romania, Russia, Spain, Sweden. The morphology of this species is generally stable. Thalli of this species consisting of many entangled filaments, forming compact masses without a distinction between erect and prostrate parts. When removed, the thalli are easily fragmented into short filaments. The cells vary in shape from globular to almost cylindrical, but mostly subglobular or elliptical (John et al., 2002; Rindi et al., 2006).

Trentepohlia spp. have been fully investigated for their taxonomy, but no data on its biological activity. Because of this, in the present study, was examined in vitro antioxidant activity and antimicrobial activity against human, animal and plant pathogens of the methanol extract of the microalga Trentepoblia umbrina (Kützing) Bornet.

\section{Materials and methods}

\section{Algal sample}

Algal sample of Trentepoblia umbrina (Kützing) Bornet, was collected from the bark of walnut (Junglas regia) in February of 2011, from Kragujevac, Serbia. For identification of algae, was used standard key (John et al., 2002). Documentation samples are deposited in the algological herbarium of the Department of Biology and Ecology, Faculty of Sciences, University of Kragujevac, Serbia.

\section{Extraction}

Air-dried algal material $(20 \mathrm{~g})$ was extracted using methanol $(200 \mathrm{ml})$ for $72 \mathrm{~h}$ at room temperature. The extract was filtered through filter paper (Whatman no. 1) and then concentrated under reduced pressure in a rotary evaporator. The dry extract was stored at $-18^{\circ} \mathrm{C}$ until they were used in the tests. The extract was dissolved in 5\% dimethyl sulphoxide (DMSO) for the experiments.

\section{Antioxidant activity}

Scavenging DPPH radicals

The free radical scavenging activity of extract was measured by 1,1-diphenyl-2-picryl-hydrazil (DPPH). The method used is similar to Dorman et al. (2004) but was modified in details. The stock solution of the extract was prepared in 5\% DMSO to achieve the concentration of $1000 \mathrm{\mu g} / \mathrm{ml}$. Further, two-fold dilutions were made to obtain concentrations of 500, 250, 125, $62.5 \mu \mathrm{g} / \mathrm{ml}$. Diluted solutions of extract $(1 \mathrm{ml}$ each) were mixed with 2 $\mathrm{ml}$ of methanol solution of DPPH radical $(0.05 \mathrm{mg} / \mathrm{ml})$ in cuvettes. The mixture was shaken vigorously and allowed to stand at room temperature for $30 \mathrm{~min}$. Then the absorbance was measured at $517 \mathrm{~nm}$ in a Jenway spectrophotometer (Bibby Scientific Limited, Stone, UK) against methanol as blank. Ascorbic acid was used as standard. The DPPH radical concentration was calculated using the following equation:
DPPH scavenging effect $(\%)=[(\mathrm{A} 0-\mathrm{A} 1) / \mathrm{A} 0] \times 100$ where $\mathrm{A} 0$ is the absorbance of the negative control $(2$ $\mathrm{ml}$ of methanol solution of DPPH radical $+1 \mathrm{ml}$ of $5 \%$ DMSO) and A1 is the absorbance of reaction mixture or standard.

The inhibition concentration at $50 \%$ inhibition $\left(\mathrm{IC}_{50}\right)$ was the parameter used to compare the radical scavenging activity. A lower $\mathrm{IC}_{50}$ meant better radical scavenging activity.

\section{Reducingpower}

The reducing power of extract was determined according to the method of Oyaizu (1986). The stock solution of the extract was prepared in 5\% DMSO to achieve the concentration of $1000 \mu \mathrm{g} / \mathrm{ml}$. Further, two-fold dilutions were made to obtain concentrations of $500,250,125,62.5$ $\mu \mathrm{g} / \mathrm{ml}$ One millilitre of each extract was mixed with $2.5 \mathrm{ml}$ of phosphate buffer $(2.5 \mathrm{ml}, 0.2 \mathrm{M}, \mathrm{pH}$ 6.6) and potassium ferricyanide $(2.5 \mathrm{ml}, 1 \%)$. The mixtures were incubated at $50^{\circ} \mathrm{C}$ for $20 \mathrm{~min}$. Then, trichloroacetic acid $(10 \%, 2.5 \mathrm{ml})$ was added to the mixture and centrifuged. Finally, the upper layer $(2.5 \mathrm{ml})$ was mixed with distilled water $(2.5 \mathrm{ml})$ and ferric chloride $(0.5 \mathrm{ml} ; 0.1 \%)$. The absorbance of the solution was measured at $700 \mathrm{~nm}$ in spectrophotometer. Blank was prepared with all the reaction agents without extract. Higher absorbance of the reaction mixture indicated that the reducing power is increased. Ascorbic acid was used as positive control.

\section{Superoxide anion radical scavenging activity}

The superoxide anion radical scavenging activity of extract was detected according to the method of Nishimiki et al. (1972). The stock solution of the extract was prepared in 5\% DMSO to achieve the concentration of 1000 $\mu \mathrm{g} / \mathrm{ml}$. Further, two-fold dilutions were made to obtain concentrations of 500, 250, 125, $62.5 \mu \mathrm{g} / \mathrm{ml}$. Briefly, 0.1 $\mathrm{ml}$ of each extract was mixed with $1 \mathrm{ml}$ nitroblue tetrazolium (NBT) solution $(156 \mu \mathrm{M}$ in $0.1 \mathrm{M}$ phosphate buffer, $\mathrm{pH} 7.4$ ) and $1 \mathrm{ml}$ nicotinamide adenine dinucleotide (NADH) solution $(468 \mu \mathrm{M}$ in $0.1 \mathrm{M}$ phosphate buffer, $\mathrm{pH}$ 7.4). The reaction was started by adding $100 \mu \mathrm{L}$ of phenazine methosulphate (PMS) solution $(60 \mu \mathrm{M}$ in 0.1 $\mathrm{M}$ phosphate buffer, $\mathrm{pH}$ 7.4). The mixture was incubated at room temperature for $5 \mathrm{~min}$, and the absorbance was measured at $560 \mathrm{~nm}$ in spectrophotometer against blank sample (phosphate buffer). Decreased absorbance indicated increased superoxide anion radical scavenging activity. Ascorbic acid was used as standard. The percentage inhibition of superoxide anion generation was calculated using the following formula:

Superoxide anion scavenging activity $(\%)=[(\mathrm{A} 0$ A1)/A0] $\times 100$

where A0 is the absorbance of the negative control (consisting of all the reaction agents except the extract) and $\mathrm{A} 1$ is the absorbance of reaction mixture or standard. 
88

The inhibition concentration at $50 \%$ inhibition $\left(\mathrm{IC}_{50}\right)$ was the parameter used to compare the radical scavenging activity. A lower $\mathrm{IC}_{50}$ meant better radical scavenging activity.

\section{Determination of total phenolic compounds}

Total soluble phenolic compounds in the extract were determined with Folin-Ciocalteu reagent according to the method of Slinkard and Singleton (1997) using pyrocatechol as a standard phenolic compound. Briefly, $1 \mathrm{ml}$ of the extract $(1 \mathrm{mg} / \mathrm{ml})$ in a volumetric flasc diluted with distilled water $(46 \mathrm{ml})$. One millilitre of Folin-Ciocalteu reagent was added and the content of the flask was mixed thoroughly. After $3 \mathrm{~min}, 3 \mathrm{ml}$ of sodium carbonate (2\%) was added and then was allowed to stand for $2 \mathrm{~h}$ with intermittent shaking. The absorbance was measured at 760 $\mathrm{nm}$ in in spectrophotometer against blank consisting of all the reaction agents except the extract. The total concentration of phenolic compounds in the extract detemined as microgram of pyrocatechol equivalent (PE) per milligram of dry extract by using an equation that was obtained from a standard pyrocatechol graph as follows:

Absorbance $=0.0057 \times$ total phenols $[\mu \mathrm{g} \mathrm{PE} / \mathrm{mg}$ of dry extracts] -0.1646

$\left(\mathrm{R}^{2}=0.9203\right)$

\section{Total flavonoid content}

The total flavonoid content was determined using the Dowd method (Meda et al., 2005). Two millilitres of 2 $\%$ aluminium trichloride $\left(\mathrm{AlCl}_{3}\right)$ in methanol was mixed with the same volume of the extract solution $(1 \mathrm{mg} / \mathrm{ml})$. The mixture was incubated at room temperature for $10 \mathrm{~min}$, and the absorbance was measured at $415 \mathrm{~nm}$ in spectrophotometer Negative control, without extract was used as the blank. The total flavonoid content determined as microgram of rutin equivalent (RE) per milligram of dry extract by using an equation that was obtained from a standard rutin graph as follows:

Absorbance $=0.0296 \times$ total flavonoid $[\mu \mathrm{g} \mathrm{RE} / \mathrm{mg}$ of dry extracts] +0.0204

$$
\left(\mathrm{R}^{2}=0.9595\right)
$$

\section{Antimicrobial activity}

Microorganisms and media

The following bacteria were used as test organisms in this study: Staphilococcus aureus (ATCC 25923), Escherichia coli (ATCC 25922), Klebsiella pneumoniae (ATCC 70063), Pseudomonas aeruginosa (ATCC 27853) and Enterococcus faecalis (ATCC 29212). All the bacteria used were obtained from the American Type Culture Collection (ATCC). Their identification was confirmed at the Microbiological Laboratory of Kragujevac, University of Kragujevac, Department of Biology. Bacterial cultures were maintained on Müller-Hinton agar substrates (Torlak, Belgrade). The fungi used as test organisms were: Aspergillus niger (DBFS 267), Candida albicans (DBFS
316), Fusarium oxysporum (DBFS 292), Penicillium purpurescens (DBFS 418) and Trichoderma harsianum (DBFS 379). All fungi were from the mycological collection maintained by the Mycological Laboratory within the Department of Biology of Kragujevac University's Faculty of Science (DBFS). Fungal cultures were maintained on potato dextrose (PD) agar except Candida albicans that was maintained on Sabourad dextrose (SD) agar (Torlak, Belgrade). All cultures were stored at $4^{\circ} \mathrm{C}$ and subcultured every 15 days.

Bacterial inoculi were obtained from bacterial cultures incubated for $24 \mathrm{~h}$ at $37^{\circ} \mathrm{C}$ on Müller-Hinton agar substrate and brought up by dilution according to the 0.5 McFarland standard to approximately $10^{8} \mathrm{CFU} / \mathrm{ml}$. Suspensions of fungal spores were prepared from fresh mature (3- to 7-day-old) cultures that grew at $30^{\circ} \mathrm{C}$ on a $\mathrm{PD}$ agar substrate. Spores were rinsed with sterile distilled water, used to determine turbidity spectrophotometrically at 530 $\mathrm{nm}$, and then further diluted to approximately $10^{6} \mathrm{CFU} /$ $\mathrm{ml}$ according to the procedure recommended by NCCLS (1998).

\section{Minimal inhibitory concentration (MIC)}

The minimal inhibitory concentration (MIC) was determined by the by the broth microdilution method with using 96-well micro-titer plates (Sarker et al., 2007). A series of dilutions with concentrations ranging from 40 to $0.156 \mathrm{mg} / \mathrm{ml}$ for extract was used in the experiment against every microorganism tested. The starting solutions of extract was obtained by measuring off a certain quantity of extract and dissolving it in DMSO. Two-fold dilutions of extracts were prepared in Müller-Hinton broth for bacterial cultures and SD broth for fungal cultures. The MIC was determined with resazurin. Resazurin is an oxidation-reduction indicator used for the evaluation of microbial growth. It is a blue non-fluorescent dye that becomes pink and fluorescent when reduced to resorufin by oxidoreductases within viable cells. The boundary dilution without any changing color of resazurin was defined as the MIC for the tested microorganism at the given concentration. As a positive control of growth inhibition, streptomycin was used in the case of bacteria, ketoconazole in the case of fungi. A DMSO solution was used as a negative control for the influence of the solvents.

\section{Statistical analyses}

All data were presented as means \pm standard deviations (mean \pm SD) of three parallel measurements. Statistical analyses was performed using using Microsoft Excel software.

\section{Results and discussion}

\section{Antioxidant activity}

The tested extract had antioxidant activity against various oxidative systems in vitro as a shown in Tab. 1 and Tab. 2. 
DPPH radical scavenging and superoxide anion radical scavenging of the studied extract are summarised in Tab. 1, while reducing power is shown in Tab. 2 . The tested extract revealed lower antioxidant activities than ascorbic acid. The $\mathrm{IC}_{50}$ values were 665.28 and $838.76 \mu \mathrm{g} / \mathrm{ml}$ for DPPH radicals and superoxide anion radicals scavenging activity, respectively. Measured values of absorbance for reducing power in the tested extract varied from 0.0086 to 0.0588 . As a shown in Tab. 2, reducing power was concentration dependant (high concentration exhibit high reducing power).

Total phenolic and flavonoid constituents of tested extract are given in Tab. 3. The amount of total phenolics and flavonoids in the extract were $35.39 \mu \mathrm{g} \mathrm{PE} / \mathrm{mg}$ and $13.72 \mu \mathrm{g} \mathrm{RE} / \mathrm{mg}$, respectively.

Free radical scavenging action is one of the numerous mechanisms for antioxidation (Sini and Devi, 2004). Antiradical activity of extract was studied by screening its possibility to bleach the stable DPPH radical. This method is based on the formation of non-radical form DPPH-H in the presence of alcoholic DPPH solution and hydrogen donating antioxidant $(\mathrm{AH})$ by the reaction $\mathrm{DPPH}+\mathrm{AH}$ $\rightarrow$ DPPH-H + A (Anandjiwala et al., 2008).

The reducing power of methanol extract of Trentepoblia umbrina also may indicate its potential antioxidant activity. The reducing features are mainly related with the presence of reductones. Gordan (1990) found that the antioxidant effect of reductones is based on the destruction of the free radical chain by donating a hydrogen atom. The reduction of ferric ion $\left(\mathrm{Fe}^{3+}\right)$ to ferrous ion $\left(\mathrm{Fe}^{2+}\right)$ is measured by the strength of the green-blue color of solution which absorbs at $700 \mathrm{~nm}$. The result presented here

Tab. 1. DPPH radical scavenging activity and superoxide anion scavenging activity of methanol extract of Trentepoblia umbrina

\begin{tabular}{ccc}
\hline & $\begin{array}{c}\text { DPPH radical } \\
\text { scavenging activity } \\
\mathrm{IC}_{50}(\mu \mathrm{g} / \mathrm{ml})\end{array}$ & $\begin{array}{c}\text { Superoxide anion } \\
\text { scavenging activity }\end{array}$ \\
$\mathrm{IC}_{50}(\mu \mathrm{g} / \mathrm{ml})$ \\
\hline Trentepoblia umbrina & 665.28 & 838.76 \\
Ascorbic acid & 6.42 & 115.61 \\
\hline
\end{tabular}

Tab. 2. Reducing power of methanol extract of Trentepoblia umbrina

\begin{tabular}{cccccc}
\hline \multicolumn{6}{c}{ Absorbance $(700 \mathrm{~nm})$} \\
\hline & 1000 & 500 & 250 & 125 & 62.5 \\
& $\mu \mathrm{g} / \mathrm{ml}$ & $\mu \mathrm{g} / \mathrm{ml}$ & $\mu \mathrm{g} / \mathrm{ml}$ & $\mu \mathrm{g} / \mathrm{ml}$ & $\mu \mathrm{g} / \mathrm{ml}$ \\
\hline T. umbrina & 0.0588 & 0.0341 & 0.0233 & 0.0124 & 0.0086 \\
Ascorbic acid & 0.2113 & 0.1654 & 0.0957 & 0.0478 & 0.0247 \\
\hline
\end{tabular}

Tab. 3. Total phenolics and flavonoid content of methanol extract of Trentepohlia umbrina

\begin{tabular}{cc}
\hline $\begin{array}{c}\text { Phenolics content } \\
(\mu \mathrm{g} \text { PE } / \mathrm{mg} \text { of extract })\end{array}$ & $\begin{array}{c}\text { Flavonoid content } \\
(\mu \mathrm{g} \text { RE/mg of extract })\end{array}$ \\
\hline 35.39 & 13.72 \\
\hline
\end{tabular}

indicates that the marked ferric reducing power activity of extract to be due to presence of polyphenols which may act in a similar way as reductones react with free radicals to turns them into more stable products and abort free radical chain reactions (Sasikumar et al., 2010).

The superoxide radical scavenging activity of methanol extract of Trentepoblia umbrina was estimated based on its ability to destroy the superoxide radical produced from the PMS/NADH reaction. Decrease in absorbance at 560 $\mathrm{nm}$ with antioxidants indicates that superoxide anion in the reaction mixture disappear (Gulcin et al., 2004).

Antioxidative nature of methanol extract of Trentepoblia umbrina might depend on its phenolics. Phenolic components are potential antioxidants. Phenolic compounds can donate hydrogen to free radicals and this way to stop the chain reaction of lipid oxidation at the initial stage. This ability of phenolic compounds to scavenge radicals comes due to the presence of their phenolic hydroxyl groups (Sawa et al., 1999). Flavonoids are widely group of natural compounds and also the most important natural phenolics. In most algae, phenols are important antioxidants because of their ability to scavenge free radicals such as singlet oxygen, superoxide and hydroxyl radicals (Shanab et al., 2011). Numerous researches found a high correlations between antioxidative activities of algae and phenolic content (Demirel et al. 2011; Sivakumar and Rajagopal, 2011) On the other hand, few studies as Heo and Cha (2005) reported that the antioxidant activity, using large number of algal species, not always correlate with the total phenolic content in each algal extract. These results may indicate the possible participation of other active substances which exhibit antioxidant activity as pigments (chlorophyll, carotenoids), essential oils, and low molecular weight polysaccharides (Murthy et al., 2005).

In the literature no data on antioxidant activity of $T r$ entepohlia umbrina, but antioxidant activity of some other green algae were studied by other researchers. For example, Shanab et al. (2011) found that the Enteromorpha compressa, Ulva lactuca and E. linza have moderate antioxidant activity. Similar results were reported by Sivakumar and Rajagopal (2011) for methanol extract from eight green algal species. Uma et al. (2011b) find an antioxidant activity for the different extracts of green microalgae Desmococcus olivaceous and Chlorococcum humicola. Compared with their results, the results of this research suggest that the methanol extract of Trentepoblia umbrina showed a relatively powerful antioxidant activity.

\section{Antimicrobial activity}

The antimicrobial activity of the tested extract against the tested microorganisms was shown in the Tab. 4.

The methanol extract of the tested microalga showed relatively similar antibacterial and antifungal activity. The MIC for extract related to the tested bacteria and fungi were $1.25-5 \mathrm{mg} / \mathrm{ml}$. The lowest measured MIC value $(1.25$ $\mathrm{mg} / \mathrm{ml}$ ) was related to the Enterococcus faecalis species. 
90

Tab. 4. Minimum inhibitory concentration (MIC) of methanol extract of Trentepohlia umbrina

\begin{tabular}{cccc}
\hline Microorganisms & Extract & S & K \\
\hline Staphylococcus aureus & 2.5 & 31.25 & - \\
Escherichia coli & 5 & 62.5 & - \\
Klebsiella pneumoniae & 2.5 & 31.25 & - \\
Pseudomonas aeruginosa & 5 & 62.5 & - \\
Enterococcus faecalis & 1.25 & 31.25 & - \\
Aspergillus niger & 5 & - & 7.81 \\
Candida albicans & 2.5 & - & 7.81 \\
Fusarium oxysporum & 2.5 & - & 3.9 \\
Penicillium purpurescens & 5 & - & 7.81 \\
Trichoderma harsianum & 2.5 & - & 3.9 \\
\hline
\end{tabular}

*Minimum inhibitory concentration ( MIC );

values given as $\mathrm{mg} / \mathrm{ml}$ for extract and as $\mu \mathrm{g} / \mathrm{ml}$ for antibiotics. Values are the mean of three replicate. Antibiotics: K - ketoconazole, S - streptomycin

The antimicrobial activity was compared to streptomycin (standard antibiotic) and ketoconazole (standard antimicotic). The results showed that streptomycin and ketoconazole had stronger activity than tested extract as shown in Tab. 4. In a negative control, DMSO had no inhibitory effect on the tested organisms.

Numerous green alga, such as Desmococcus olivaceous, Chlorococcum humicola, Chlorella vulgaris, Ulva fasciata, Enteromorpha intestinalis, Chaetomorpha aerea were screened for antimicrobial activity in search of the new antimicrobial agents (Seenivasan et al., 2010; Uma et al., 2011a), but in this study, for the first time, the antimicrobial activity of the methanol extract of Trentepoblia umbrina was investigated. In correlation with results obtained in experiments with other algae, we noticed that the methanol extract of Trentepohlia umbrina showed relatively strong antimicrobial activity.

In these experiments, the examined extract in the same concentrations showed a slightly stronger antibacterial than antifungal activity. These results could be expected due to the fact that numerous tests proved that bacteria are more sensitive to the antibiotic compared to fungi (Hugo and Russell, 1983). The reason for different sensitivity between the fungi and bacteria can be found in different transparency of the cell wall. The cell wall of the grampositive bacteria consists of peptidoglycan (murein) and teichoic acids, while the cell wall of the gram-negative bacteria consists of lipo polysaccharides and lipopoliproteins (Heijenoort, 2001) whereas, the cell wall of fungi consists of polysaccharides such as hitchin and glucan (Farkaš, 2003).

\section{Conclusions}

In conclusion, it can be stated that tested extract had a certain level of antioxidant and antimicrobial activity in vitro, which suggest that Trentepoblia umbrina could be natural antioxidant and antimicrobial agents. Further studies should be done on the isolation and characteriza- tion of pure compounds from this algae, which are responsible for its antioxidant and antimicrobial activities.

\section{Acknowledgements}

This work was financed in part by the Ministry of Science, Technology, and Development of the Republic of Serbia and was carried out within the framework of projects no. III43002 and 173032.

\section{References}

Abe K, Mihara H, Hirano M (1998). Characteristics of growth and carotenoid accumulation of the aerial microalga Trentepohlia aurea in liquid culture. J Mar Biotechnol 6:5358.

Anandjiwala S, Bagul MS, Parabia M, Rajani M (2008). Evaluation of free radical scavenging activity of an ayurvedic formulation, Panchvalkala. Ind J Pharm Sci 70:31-35.

Athar Abbasi M, Rubab K, Aziz-ur-Rehman, Tauheeda Riaz T, Shahzadi T, Khalid M, Ajaib M (2012). In vitro assessment of relief to oxidative stress by different fractions of Boerhavia procumbens. Pak J Pharm Sci 25:357-364.

De lara Isassi G, Alvarez-Hernandez S, Collado-Vides L (2000). Ichtyotoxic activity of extracts from Mexico marine macroalgae. J Appl Phycol 12:45-52.

Demirel Z, Yilmaz-Koz FF, Karabay-Yavasoglu NU, Ozdemir G, Sukatar A (2011). Antimicrobial and antioxidant activities of solvent extracts and the essential oil composition of Laurencia obtusa and Laurencia obtusa var. pyramidata. Rom Biotech Lett 16:5927-5936.

Dorman HJ, Bachmayer O, Kosar M, Hiltunen R (2004). Antioxidant properties of aqueous extracts from selected Lamiaceae species grown in Turkey. J Agr Food Chem 52:762-770.

Ely R, Supriya T, Naaik CG (2004). Antimicrobial activity of marine organisms collected of the coast of South East India. J Exp Bio Ecol 309:121-127.

Farkaš V (2003). Structure and biosynthesis of fungal cell walls: Methodological approaches. Folia Microbiol 48:469-478.

Gordan MH (1990). Food antioxidants, Elsevier, London, New York, $18 \mathrm{p}$.

Gulcin I, Kurfrevioglu OI, Oktay M, Buyukokuroglu ME (2004). Antioxidant, antimicrobial, antiulcer and analgesic activities of nettle (Urtica dioica L.). J Ethnopharmacol 90:205-215.

Heijenoort J (2001). Formation of the glycan chains in the synthesis of bacterial peptidoglycan. Glycobiology 11:2536.

Heo SJ, Cha SH (2005). Antioxidant activities of chlorophyta and phaeophyta from Jeju Island. Algae 20:251-260.

Hugo WB, Russell AD (1983). Pharmaceutical microbiology, $3^{\text {rd }}$ edition, Blackwell Scientific Publications, 470 p.

John DM, Whitton BA, Brook AJ (2002). The Freshwater Algal Flora of the British Isles: An Identification Guide to 
Freshwater and Terrestrial Algae. Cambridge, Cambridge University Press, $714 \mathrm{p}$.

Justo GZ, Silva MR, Queiroz MLS (2001). Effects of green algae Chlorella vulgaris on the response of the host hematopoietic system to intraperitoneal ehrlich ascites tumour transplantation in mice. Immunopharm Immunot 23:199-131.

Kosanić M, Ranković B, Vukojević J (2011). Antioxidant properties of some lichen species, J Food Sci Tech Mys 48:584-590

Meda A, Lamien CE, Romito M, Millogo J, Nacoulma OG (2005). Determination of the total phenolic, flavonoid and proline contents in burkina fasan honey, as well as their radical scavenging activity. Food Chem 91:571-577.

Murthy KNC, Vanilha A, Rajesha J, Swamy MM, Swmya PR, Ravishankar GA (2005). In vitro antioxidant activity of carotenoids from Dunaliella salina-a green microalga. Life Sci 76:1381-1390.

NCCLS (National Commitee for Clinical Laboratory Standards) (1998). Reference Method for Broth Dilution Antifungal Susceptibility Testing of Conidium-forming Filamentous Fungi: Proposed Standard M38-P. NCCLS, Wayne, PA, USA.

Nishimiki M, Rao NA, Yagi K (1972). The occurrence of super-oxide anion in the reaction of reduced phenazine methosulfate and molecular oxygen. Biochem Biophys Res Commun 46:849-853.

Oyaizu M (1986). Studies on products of browning reaction prepared from glucoseamine. Jpn J Nutr 44:307-314.

Rindi F, Guiry MD, López-Bautista JM (2006). New records of Trentepohliales (Ulvophyceae, Chlorophyta) from Africa. Nova Hedwigia 83:431-449.

Saeidnia S, Gohari AR, Shahverdi AR, Permeh P, Nasiri M, Mollazadeh K (2009). Biological activity of two red algae, Gracilaria salicornia and Hypnea flagelliformis from persian gulf. Pharmacogn Res 1:428-430.

Sarker SD, Nahar L, Kumarasamy Y (2007). Microtitre platebased antibacterial assay incorporating resazurin as an indicator of cell growth, and its application in the in vitro antibacterial screening of phytochemicals. Methods 42:321324.
Sarma P (1986). The freshwater Chaetophorales of New Zealand. Beih Nova Hedwigia 58:1-169.

Sasikumar JM, Mathew GM, Teepica PDD (2010). Comparative studies on antioxidant activity of methanol extract and flavonoid fraction of Nyctanthes arbortristis leaves. EJEAFChe 9:227-233.

Sawa T, Nakao M, Akaike T, Ono K, Maeda H (1999). Alkylperoxyl radical scavenging activity of various flavonoids and other phenolic compounds: Implications for the antitumor promoter effect of vegetables. J Agric Food Chem 47:397-492.

Seenivasan R, Indu H, Archana G, Geetha S (2010). The antibacterial activity of some marine algae from south east coast of India. J Pharm Res 3:1907-1912.

ShanabSMM,ShalabyEA,El-FayoumEA (2011).Enteromorpha compressa Exhibits Potent Antioxidant Activity. J Biomed Biotechnol doi:10.1155/2011/726405

Sini H, Devi KS (2004). Antioxidant activities of chloroform extract of Solanum trilobatum. Pharm Biol 42:462-466.

Sivakumar K, Rajagopal SV (2011). Radical scavenging activity of green algal species. J Pharm Res 4:723-725.

Slinkard K, Slingleton VL (1997). Total phenolic analyses: automation and comparison with manual method. Am J Enol Viticult 28:49-55.

Souri E, Amin G, Farsam H, Jalalizadeh H, Barezi S (2008). Screening of Thirteen Medicinal Plant Extracts for Antioxidant Activity. Iran J Pharm Res 7:149-154.

Tuney I, Cadirci BH, Unal D, Sukatar A (2006). Antimicrobial activities of the extracts of marine algae from the coast of Urla (Izmir, Turkey). Turk J Biol 30:171-175.

Uma R, Sivasubramanian V, Niranjali Devaraj S (2011a). Preliminary phycochemical analysis and in vitro antibacterial screening of green micro algae, Desmococcus olivaceous, Chlorococcum bumicola and Chlorella vulgaris. J Algal Biomass Utln 2:74-81.

Uma R, Sivasubramanian V, Niranjali Devaraj S (2011b). Evaluation of in vitro antioxidant activities and antiproliferative activity of green microalgae, Desmococcus olivaceous and Chlorococcum humicola. J Algal Biomass Utln 2:82-93. 